\title{
EFFECT OF SWIM-UP AND GLASS WOOL TECHNIQUES, WITH ADDING ANTIOXIDANTS TO TRIS EXTENDER ON IMPROVING POST- CRYOPRESERVED SOME SEMEN ATTRIBUTES OF LOW SEMEN QUALITY FOR HOLSTEIN BULLS
M. S. Hassan ${ }^{1}$
Assist. Prof.
S. M. Eidan ${ }^{2}$
Prof. \\ ${ }^{1}$ College of Veterinary Medicine, University of Kerbela; Kerbela; Iraq. \\ ${ }^{2}$ College of Agricultural Engineering Sciences, University of Baghdad; Baghdad, Iraq. mayada.s@uokerbala.edu.iq_sajeda.mahdi@coagri.uobaghdad.edu.iq
}

\section{ABSTRACT}

This study was conducted to investigate the effect of swim-up and glass wool as sperm separation techniques with adding vitamin $E$ and superoxide dismutase (SOD) to Tris extender on improving some post-cryopreserved semen quality for Holstein bulls. Low and good of semen were extended using Tris extender. Good semen quality (GSQ) was divided into 3 groups (L1; Tris extender, L2; 2 $\mathrm{mM}$ vitamin E, L3; 200 IU SOD) Low semen quality (LSQ) was divided into two main groups, and subdivided into 3 sub-groups (L4; Tris extender, L5; 2 mM vitamin E, L6; 200 IU SOD). In the second main group, swim-up and glass wool techniques were used with adding vitamin $E$ and SOD and subdivided into 3 sub-groups with each technique, and referred to L7, L8 and L9 for swim-up technique and L10, L11 and L12 for glass wool technique. Improving sperms' cell motility and live sperm and reducing total sperms' abnormalities percentages of low semen quality were noticed using swim-up and glass wool techniques were used with adding vitamin $E$ and SOD. In conclusion, glass wool filtration separates out dead, abnormal and immotile sperm cells, a good sperm harvested by this technique.

Keywords: Vitamin E, SOD, Swim-up, Glass wool, Low semen quality, Holstein bulls.

حسن وعيدان مجلة العلوم الزراعية العراقية -563-552:52:2021 م2 (3) تأثير تقانات Swim-up والصوف الزجاجي مع إضافة مضادات الأكسدة الى مخفف

$$
\begin{aligned}
& \text { في تحسين بعض صفات السائل المنوي رديء النوعية لثيران الهولثتاين بعد الحفظ بالتبريد والتجميد } \\
& \text { ساجدة مهري عيدان } 2 \\
& \text { استاذ } \\
& \text { ميادة صاحب حسن } 1 \\
& \text { استاذ مساعد } \\
& \text { 2 كلية علوم الهندسة الزراعية- جامعة بغداد. } \\
& \text { 1كلية الطب البيطري - جامعة كربلاء }
\end{aligned}
$$

المستخلص

أجريت هذه الدراسة لبيان تأثير تقانات Swim-up والصوف الزجاجي لفصل النطف مع إضافة فيتامين E والسوير أوكسيد دسميوتيز (SOD) الى مخفق Tris في تحسين بعض صفات السائل المنوي رديء النوعية لثيران الهولثتاين بعد الحفظ بالتبريد والتجميد. تم تخفيف كلا النوعين من السائل المنوي بإستخدام مخفف Tris. قسم السائل المنوي الجيد النوعية الى 3 مجاميع (L1: مخفف Tris، L2: 2 ملي مايكرون فيتامين E2، L3: 200 وحدة دولية من SOD)، كما قسم السائل المنوي

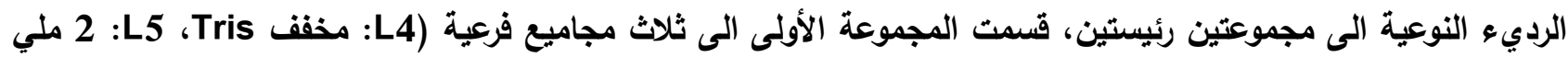

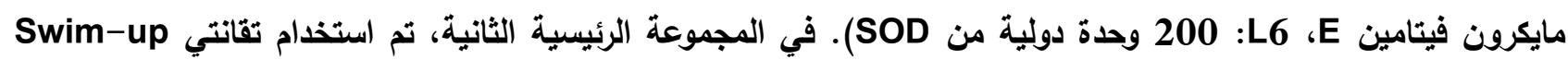
والصوف الزجاجي لفصل النطف مع إضافة فيتامين E و SOD تم تقسيم كل مجموعة من مجموعتي التقانات الى ثلاث مجاميع

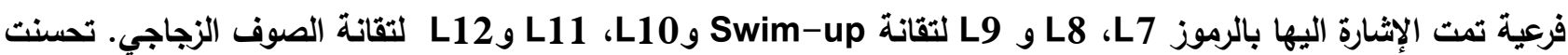
النسبة المئوية لحركة النطف الفردية والنطف الحية وإنخفضت النسبة المئوية للنطف المشوهة الكلية بإستخدام تقانات والصوف الزجاجي مع إضافة فيتامين Ewim-up و وSOD. يمكن الاستتتاج بأن تقانة الصوف الزجاجي تعمل على فصل

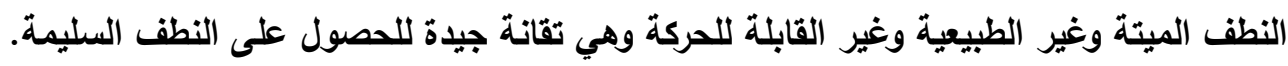
الكلمات المفتاحية: فيتامين Ewim-up SOD، ، الصوف الزجاجي، السائل المنوي رديء النوعية، ثيران الهولثتاين. 


\section{INTRODUCTION}

The enhancement in quality of semen is crucial aspect for maximum utilization of genetically-superior sub-fertile sire, for the reason of age and/or non-specific factors like thermal stress, transport and vaccination stress during their dynamic life show a low-grade semen quality than previously (49). In Iraq, increasing quantities of poor-quality semen from genetically-superior bulls used in artificial insemination (AI) center, at moderate season (October and November) in particular (5), is a big burden and of economic loss, namely, \$ 3-4 per bull per day (personal communication). These will negatively reflect in low conception rates of cattle herds as well as to decrease in their breeder income (8). Using of semen separation techniques for invitro fertilization (IVF) processes became an important routine work for yielding a higher number of motile and morphologically normal spermatozoa that would be successfully used for long-term cryopreservation processes (62). The basic presupposition of any sperm preparation technique is to (a) eliminate any factors detrimental to fertilization, (b) to block factors such as prostaglandins that would otherwise cause uterine contractions, (c) to increase sperm concentration, motility and (d) to form sperm capacitation. This is to be achieved by separating the seminal plasma from spermatozoa in a rapid and efficient fashion (32). Swim-up technique is based on migration of motile sperm from the bottom to the top fraction of the media, which separates motile sperms from the non-motile sperm and debris, as it is based on the ability of sperm to swim into the culture medium. This method may be performed by layering the culture medium directly over the semen, or layering the culture medium over the pellet, which is obtained after the centrifugation of the sample (57). This technique is an easy reliable and effective sperm processing method for insemination purposes, and an increased sperm count, motility and pregnancy rate were obtained after the swim up procedure in human (35). Moreover, Risopatrón, (49) found $63.20 \%$ of bull's live sperm with intact plasma membrane using swim up technique. Glass wool filtration is a low-cost, simple, and highly effective procedure to select functionally competent sperm for reproductive technologies in the bull, which may be useful for other domestic and farm animals, as well as for endangered species $(11,14)$. Greater sperm's cell individual motility and plasma membrane integrity percentages of postthawed bull's semen samples noticed as compared with the control group using glass wool technique (36). The continuous releasing of reactive oxygen species (ROS) from abnormal and immature sperms, as well as those produced from freezing-thawing processes is often accompanied by low concentrations of antioxidants in seminal plasma and semen extenders. That would consequently lead to deleterious effects of oxidative stress on spermatozoa (59). vitamin $\mathrm{E}$ is a fat-soluble compound and also known as $\alpha$-tocopherol (61). It acts as most effective non-enzymatic antioxidants due to its ability to inhibit free radicals). Overwhelming results of improved post-cryopreserved (PC) semen quality of Holstein bulls were obtained by adding vitamin $\mathrm{E}$ to Tris extender (2, 3, 7, 23). On the other hand, superoxide dismutase (SOD) is an antioxidant that catalyzes dismutation of superoxide into oxygen and hydrogen peroxide. It scavenges both extracellular and intracellular superoxide anion and prevents lipid peroxidation of the plasma membrane (19). A good result of cooled (12) and cryopreserved (41) semen characteristics of bulls were got with adding SOD to semen extenders. The comparison among the abovementioned semen separation techniques with adding vitamin $\mathrm{E}$ or SOD and their effects on low-quality semen characteristics of Holstein bulls were not previously investigated either in Iraq or in the world. Therefore, this study was undertaken to investigate the effect of using swim-up and glass wool techniques with adding vitamin $\mathrm{E}$ or SOD to separated, low and good-quality semen on improving postcryopreserved sperm's cell individual motility, live sperm and sperm's abnormality percentages pertaining to low semen quality of Holstein bulls. This study was aimed the effect of using swim-up and glass wool techniques with addition of vitamin $\mathrm{E}$ or SOD to separated, low and good- quality semen on PC sperm characteristics of Holstein bulls. 


\section{MATERIALS AND METHODS}

This study was undertaken at the Department of Artificial Insemination pertaining to the Directorate of Animal Resource, Ministry of Agriculture, Abu-Ghraib, Baghdad, during the period from February, 2018 to May 2019 using twelve Holstein bulls. Both low fresh semen (sperm's cell individual motility less than 40\%) from nine bulls and good fresh semen quality from three bulls were collected via artificial vagina at two ejaculates\ bull /week. Determination of ejaculate volume was done using graduate tube, while, sperm concentration was calculated using Neubauer Haemocytometer Counting Chamber (50). The sperm's cell individual motility percentage for all treatments at $5^{\circ} \mathrm{C}$ cooling, $96 \mathrm{hrs}$., 3- and 6mon. post-cryopreservation; PC months was estimated according to Walton (59). Live sperm percentage was estimated based on Swanson (54) method. Abnormal sperm percentage was determined according to the methods described by (29) using eosinnigrosin staining technique with similar slide for live sperm estimation. Swim-up technique as described by (44). Parameters were assessed at four preservation periods (cooling, $96 \mathrm{hrs.,3}$ and 6-months post-cryopreservation; PC).

\section{Statistical analyses}

The statistical computation was performed using SAS program (52) based on study on completely randomized deign (CRD) to study the effect of different factors on the studies characteristics. Means with significant differences were compared using Duncan multiple range test (21).

\section{RESULTS AND DISCUSSION Sperm's cell individual motility percentage}

All groups were superior $(\mathrm{P} \leq 0.0001)$ in sperm's cell motility percentage $(49.29 \pm 3.69$ $68.75 \pm 1.25 \%$ ) as compared with the L4 group $(35.00 \pm 3.09 \%)$ at cooling period (Table 1). Furthermore, Non-significant differences were observed among L1, L2, L3, L5, L8, L9, L10, L11, and L12 groups in sperm's cell motility percentage at cooling period (Table 1). Highly significant $(\mathrm{P} \leq 0.0001)$ differences were showed in sperm's cell motility among groups after 96 hrs. PC period (Table 1). The L3 group recorded highest percentage of sperm's cell motility $(63.75 \pm 1.25 \%)$ and the L4 group was the lowest $((30.71 \pm 3.10 \%$; Table 1$)$. Non- significant differences were observed among L1, L2, L3, L8, L9, L11 and L12 groups and also among L1, L2, L5, L8, L9, L10, L11, andL12 groups at $96 \mathrm{hrs}$. PC period (Table 1). On the other hand, all groups demonstrated greater $(\mathrm{P} \leq 0.0001)$ sperm's cell motility percentages $(42.14 \pm 3.43-58.75 \pm 1.25 \%)$ as compared with the L4 group $(30.00 \pm 3.93 \%)$, 3-month PC period (Table 1). Moreover, nonsignificant differences were noticed among all good semen quality groups (L1, L2, and L3), glass wool separation technique groups (L10, L11, and L12) and L5 group for similar trait and period (Table 1). Furthermore, the differences among L1, L9, L10, L11, and L12 groups lacked significance (Table 1). The results revealed greatest $(\mathrm{P} \leq 0.0001)$ sperm's cell motility percentage in all groups in comparison with L4 group, 6 months PC for (Table 1). On the other hands, non-obvious differences were showed among L1, L2, L3, L10, L11, L12 groups, among L5, L6, L7, L8, L9, L10, L11, as well as L12 group for similar trait and period (Table 1). Non-significant differences were observed at different preservation periods in L1, L2, L4, L6, L7, L9, and L11 groups (Table 1). Greater sperm's cell motility percentages were recorded at cooling period $(\mathrm{P} \leq 0.005$ and $\mathrm{P} \leq 0.03)$ in comparison with $3^{\text {rd }}$ and $6^{\text {th }}$ month PC periods within L3, 18, and L10 groups (Table 1). On the other hands, non- significant differences were observed among all PC periods within L3, L8, and L10 groups (Table 1). The sperm's cell motility percentages were increased at cooling period as compared with $6^{\text {th }}$ month's PC period in L5, and L9 groups (Table 1). Moreover, non-significant differences were noticed among all PC periods in L5 and L9 groups (Table 1). The cooling period was recorded more $(\mathrm{P} \leq 0.0001)$ sperm's cell motility percentage in comparison with all PC periods in L12 group (Table 1). The sperm's cell motility percentage was increased at 96 hrs. in comparison with the $3^{\text {rd }}$, and $6^{\text {th }}$ months PC period in L12 group (Table 1). The sperm's cell motility percentage in the L2 group (good semen quality plus vitamin E) did not differ with the L1 group (Good semen quality) at cooling period. These results were inconsistent with (7) finding, who found higher $(\mathrm{P}<0.01)$ sperm's cell motility percentage when adding 
$0.2 \mathrm{mM}$ vitamin $\mathrm{E}$ to Tris extender $(54.29 \pm 2.02 \%)$ as compared with control group (Tris extender, $45.71 \pm 3.680 \%$ ) at cooling period in Holstein bull's semen. Also (51) was disagreed with the current results who figure out higher $(\mathrm{P}<0.05)$ sperm motility in $0.2 \mathrm{mM}$ vitamin group $(63.33 \pm 1.02 \%)$ than Tris group $(55.83 \pm 1.04 \%)$ at cooling period in Beetal bucks. Our results were also disagreed with (2), who illustrated greater $(\mathrm{P}<0.01)$ sperm's cell motility percentage of Holstein bulls, in $0.2 \mathrm{mM}$ vitamin $\mathrm{E}$ group $(54.29 \pm 2.02$ $\%)$ as compared with control group (Tris extender, $45.71 \pm 3.68 \%$ ) at cooling period. The current results revealed non- significant differences between L1 and L2 groups at different PC periods. These findings were consistent with those reported by (13), who didn't find significance differences for sperm motility between vitamin $\mathrm{E}$ group $(0.1 \mathrm{mM}$, $56.98 \pm 0.05 \%)$ and control group $(45.86 \pm 0.18$ $\%)$ at PC period for buffalo bull's semen. Our results were also agreed with results of $(7,30)$ who didn't find significance differences at PC periods in Holstein and Simmental bulls, while it disagreed with $(2,34)$ results who found a higher $(\mathrm{P}<0.05)$ sperm motility when added vitamin $\mathrm{E}$ to the extender as compared with control group at PC periods. The superiority of vitamin $\mathrm{E}$ groups with or without sperm separation techniques as compared with L4 (negative control group) may return to the role of vitamin $\mathrm{E}$ as potential antioxidant. Vitamin $\mathrm{E}$ is the first line of defense against lipid peroxidation and it is important for normal function and immune cells (45). Vitamin $\mathrm{E}$ has a positive role in improving semen quality via protecting testicular cell membrane and mitochondria from antioxidant abilities (61). The vitamin $\mathrm{E}$ protects the cell membrane of sperm cell from damages of ROS through a chain-breaking antioxidant to inhibit the propagation step $(17,26,60)$. The vitamin $E$ donates its phenolic hydrogen atom to a peroxyl radical and converts it to a hydroperoxide. The L3 group illustrated nonsignificant differences with L1 group at all PC periods. These results were concurrent with $(12,46)$ findings and disagreed with Murtaza (42) who found that sperm's cell motility percentage was decreased when added $200 \mathrm{IU}$ SOD to Tris extender $(45.00 \pm 0.408 \%)$ as compared with control group (Tris extender) in Sahiwal bull semen. Daghigh and Griveau (18, 28) pointed out that SOD resulted in higher motility of epididymal bull sperm post cryopreservation, these results was disagreement with our result. The adding of SOD to semen extender with good or bad quality semen, swim-up and glass wool sperm separation had improved of motility at different preservation periods (Table 1). The SOD considers very importance of defense strategy against oxidative stress. The testes contain not only the conventional mitochondrial $(\mathrm{Fe} / \mathrm{Mn})$ and cytosolic $(\mathrm{Cu} / \mathrm{Zn})$ forms of SOD, but also feature an unusual form of extracellular SOD, (SOD-Ex) which is produced by both Sertoli and germ cells, particularly the former. The SOD scavenges both intracellular and extracellular superoxide anion and prevents lipid peroxidation of the plasma membrane $(19,46)$. Membrane of mammalian sperm has high poly unsaturated fatty acids. Poly unsaturated fatty acids make a sperm very susceptible to lipid peroxidation, which occurs as a result of the oxidation of the membrane lipids by partially reduced oxygen molecules, such as hydrogen peroxide, hydroxyl radicals, and superoxide $(12,46)$. Lipid peroxidation of the sperm membrane leads to the deterioration of sperm function due to the attacks by reactive oxygen species, altered sperm membrane integrity, motility, and damage to sperm DNA and fertility through oxidative stress and the production of cytotoxic aldehydes $(28,50)$. The levels of antioxidant decreased during the preservation process by dilution of semen with extender and excessive generation of reactive oxygen species molecules (51). Natural and synthetic antioxidant systems have been described as a defense functioning mechanism against lipid peroxidation in semen $(2,3,4,22,24,39,40$, 46). The lowest motility percentage in the L4 group (Bad semen quality) may due to decrease level of antioxidants like SOD, catalase, glutathione peroxidase vitamin C, E...etc. reduced quantity of seminal SOD results in poor quality of semen as well as reproductive functions (65). This was evident in the current study when adding SOD or vitamin $\mathrm{E}$ to semen extender with and without sperm separation technique, the sperm motility 
was efficiently improved (Table 1). Our results were improved sperm's cell motility percentage by using swim-up and glass wool sperm separation techniques. These results were agreed with the previous results of $(6,10$, $27,31,36,38,56)$ in frozen thawed cattle bull, buffalo bull, fresh ram semen, and fresh

Table 1. Effect of swim-up and glass wool set

Table 1. Effect of swim-up and glass wool separation techniques and adding of superoxide

dismutase or vitamin E to semen extender on post-cryopreserved (PC) sperm's cell motility percentage of Holstein bulls semen (Mean \pm SE).

\begin{tabular}{|c|c|c|c|c|c|}
\hline Groups & $\begin{array}{l}\text { Cooling } \\
5^{\circ} \mathrm{C}\end{array}$ & $\begin{array}{l}96 \text { hrs. } \\
\text { PC }\end{array}$ & $\begin{array}{c}3 \text { months } \\
\text { PC }\end{array}$ & $\begin{array}{c}6 \text { months } \\
\text { PC }\end{array}$ & $\begin{array}{c}\text { Level of } \\
\text { Significance }\end{array}$ \\
\hline L1 & $\begin{array}{c}57.14 \pm 2.64 \text { bcd } \\
\text { A }\end{array}$ & $\begin{array}{c}55.71 \pm 2.02 \text { abc } \\
\text { A }\end{array}$ & $\begin{array}{c}55.42 \pm 2.12 \text { abc } \\
\text { A }\end{array}$ & $\begin{array}{c}55.00 \pm 1.54 \text { a } \\
\text { A }\end{array}$ & N.S. \\
\hline L2 & $\begin{array}{c}61.00 \pm 5.05 \text { abc } \\
A\end{array}$ & $\begin{array}{c}60.00 \pm 5.00 a b \\
A\end{array}$ & $\begin{array}{c}56.67 \pm 4.41 \text { ab } \\
A\end{array}$ & $\begin{array}{c}55.67 \pm 4.39 \text { a } \\
A\end{array}$ & N.S. \\
\hline L3 & $\begin{array}{c}68.75 \pm 1.25 \mathrm{a} \\
\mathrm{A}\end{array}$ & $\begin{array}{c}63.75 \pm 1.25 \mathrm{a} \\
\mathrm{AB}\end{array}$ & $\begin{array}{c}58.75 \pm 1.25 \text { a } \\
\text { B }\end{array}$ & $\begin{array}{c}57.50 \pm 3.23 \text { a } \\
\text { B }\end{array}$ & $P \leq \mathbf{0 . 0 0 5}$ \\
\hline L4 & $\begin{array}{c}35.00 \pm 3.09 \\
\text { A }\end{array}$ & $\begin{array}{c}30.71 \pm 3.10 \mathrm{e} \\
\mathrm{A}\end{array}$ & $\begin{array}{c}30.00 \pm 3.93 \mathrm{e} \\
\mathrm{A}\end{array}$ & $\begin{array}{c}30.00 \pm 3.87 \mathrm{c} \\
\mathrm{A}\end{array}$ & N.S. \\
\hline L5 & $\begin{array}{c}53.57 \pm 2.83 \text { bed } \\
\text { A }\end{array}$ & $\begin{array}{c}50.00 \pm 2.18 \text { bed } \\
\text { AB }\end{array}$ & $\begin{array}{c}47.14 \pm 2.86 \text { abcd } \\
\text { AB }\end{array}$ & $\begin{array}{c}42.86 \pm 2.40 \mathrm{~b} \\
\mathrm{~B}\end{array}$ & $P \leq 0.04$ \\
\hline L6 & $\begin{array}{c}50.00 \pm 2.67 \mathrm{~cd} \\
\mathrm{~A}\end{array}$ & $\begin{array}{c}46.43 \pm 2.37 \mathrm{~cd} \\
\mathrm{~A}\end{array}$ & $\begin{array}{c}44.29 \pm 3.52 \mathrm{~cd} \\
\mathrm{~A}\end{array}$ & $\begin{array}{c}40.00 \pm 3.27 \\
\mathrm{~A}\end{array}$ & N.S. \\
\hline L7 & $\begin{array}{c}49.29 \pm 3.69 \mathrm{~d} \\
\mathrm{~A}\end{array}$ & $\begin{array}{c}43.57 \pm 3.73 \mathrm{~d} \\
\mathrm{~A}\end{array}$ & $\begin{array}{c}42.14 \pm 3.43 \mathrm{~d} \\
\mathrm{~A}\end{array}$ & $\begin{array}{c}41.43 \pm 3.57 b \\
A\end{array}$ & N.S. \\
\hline L8 & $\begin{array}{c}57.89 \pm 1.84 \text { bcd } \\
\text { A }\end{array}$ & $\begin{array}{c}52.86 \pm 2.14 \text { abcd } \\
\text { AB }\end{array}$ & $\begin{array}{c}43.57 \pm 4.74 d \\
B\end{array}$ & $\begin{array}{c}43.50 \pm 4.84 b \\
B\end{array}$ & $P \leq 0.02$ \\
\hline L9 & $\begin{array}{c}57.87 \pm 3.76 \text { bcd } \\
\text { A }\end{array}$ & $\begin{array}{c}52.85 \pm 4.06 \text { abcd } \\
\text { AB }\end{array}$ & $\begin{array}{c}45.71 \pm 4.56 \mathrm{bcd} \\
\text { AB }\end{array}$ & $\begin{array}{c}43.57 \pm 3.89 \text { b } \\
\text { B }\end{array}$ & N.S. \\
\hline L10 & $\begin{array}{c}59.29 \pm 2.97 \text { abcd } \\
\text { A }\end{array}$ & $\begin{array}{c}50.71 \pm 3.10 \text { bcd } \\
\text { AB }\end{array}$ & $\begin{array}{c}47.14 \pm 2.86 \text { abcd } \\
\text { B }\end{array}$ & $\begin{array}{c}46.43 \pm 2.61 \mathrm{ab} \\
\text { B }\end{array}$ & $P \leq 0.03$ \\
\hline L11 & $\begin{array}{c}62.14 \pm 2.40 \mathrm{ab} \\
\mathrm{A}\end{array}$ & $\begin{array}{c}55.00 \pm 3.78 \text { abc } \\
\text { A }\end{array}$ & $\begin{array}{c}50.71 \pm 3.69 \text { abcd } \\
\text { A }\end{array}$ & $\begin{array}{c}50.00 \pm 3.45 \mathrm{ab} \\
\mathrm{A}\end{array}$ & N.S. \\
\hline L12 & $\begin{array}{c}68.57 \pm 1.80 \mathrm{a} \\
\mathrm{A}\end{array}$ & $\begin{array}{c}57.86 \pm 2.14 \text { ab } \\
\text { B }\end{array}$ & $\begin{array}{c}47.86 \pm 1.01 \text { abcd } \\
\text { C }\end{array}$ & $\begin{array}{c}46.43 \pm 0.92 \mathrm{ab} \\
\mathrm{C}\end{array}$ & $P \leq 0.0001$ \\
\hline $\begin{array}{c}\text { Level of } \\
\text { Significance }\end{array}$ & $P \leq 0.0001$ & $P \leq 0.0001$ & $P \leq 0.0001$ & $P \leq 0.0001$ & --- \\
\hline
\end{tabular}

Means with small superscripts within each column indicated significant differences among groups and large superscripts within each row indicated significant differences among periods; N.S.= no significant; L1= Good Semen Quality (GSQ) + Tris extender; L2= GSQ + Tris extender + $2 \mathrm{mM}$ vitamin E; L3= GSQ + Tris extender + 200 IU SOD; L4= Low Semen Quality (LSQ) + Tris extender; L5= LSQ + Tris extender + 2 mM vit. E; L6= LSQ + Tris extender + 200 IU SOD; L7= SU Semen tech.+Tris extender; L8= SU Semen tech.+ Tris extender $+2 \mathrm{mM}$ vit. E; L9= SU Semen tech.+Tris extender + 200 IU SOD; L10= GW Semen tech.+ Tris extender; L11= GW Semen tech.+ Tris extender $+2 \mathrm{mMvit}$. E, L12= GW Semen tech. + Tris extender + 200 IU SOD.

\section{Live sperm percentage}

Higher $(\mathrm{P} \leq 0.0001)$ live sperm percentage were observed in good quality semen groups (L1L3) and glass wool separation groups (L10L12) as compared with the low semen quality groups (L4-L6), and swim-up separation groups (L7, and L9) at the cooling period (Table 2). Non- significant differences in live sperm percentage were noticed at the cooling among L1-L3 and L10-L12 groups, among L4-L9 groups and also among L8, and L10L12 groups (Table 2). The live sperm percentage were greater $(\mathrm{P} \leq 0.0001)$ in $\mathrm{L} 1-\mathrm{L} 3$ and L8- L12 groups in comparison with L4-L7 groups at $96 \mathrm{hrs}$. PC period (Table 2). The highest live sperm percentage was showed in L2 group $(85.00 \pm 2.00)$ and lesser in L4-L7 $(62.07 \pm 2.76-63.14 \pm 1.71 \%)$ at 96 hrs. PC period (Table 2). They were no significant differences in live sperm percentage among the L1-L3, L10, and the L12 groups, an among the L4-L9 groups and also among the L1 and the L8-L11 groups at $96 \mathrm{hrs}$. PC period (Table 2). There were significant differences $(\mathrm{P} \leq 0.0001)$ in live sperm percentages among groups. The L2 was recorded highest live sperm $(82.25 \pm 0.75 \%)$, while the L4 $(58.36 \pm 1.59 \%)$ group was lowest at $3^{\text {rd }} \mathrm{PC}$ period (Table 2). Non- significant differences were observed among good quality groups 
(L1-L3), among L1, L3, and glass wool separation groups (L10-L12) at $3^{\text {rd }}$ months PC period (Table 2). The L5-L9 groups exhibited non- significance differences in live sperm percentage as well as among low quality groups (L4-L6) at $3^{\text {rd }}$ months PC period (Table $2)$. The L1-L3 $(76.29 \pm 1.72-81.25 \pm 3.25 \%)$ groups revealed higher $(\mathrm{P} \leq 0.0001)$ than $\mathrm{L} 4-\mathrm{L} 9$ groups $(56.50 \pm 2.33-64.93 \pm 3.67 \%)$ at $6^{\text {th }}$ months PC period (Table 2). Furthermore, the L10-L12 groups exhibited significant differences $(\mathrm{P} \leq 0.0001)$ in comparison with the L4-L7 groups at 6th months PC period (Table $2)$. On the other hand, non- significant was noticed among the L1, L3, and the L10-L12 groups as well among L4-L9 at $6^{\text {th }}$ PC period (Table 2). The cooling period exhibited higher $(\mathrm{P} \leq 0.005)$ percentage of live sperm as compared with the other PC periods in L1, L5L8, and L11 groups (Table 2). On the other hand, non- significant differences were noticed among all PC periods (Table 2). Nonsignificant differences in were showed among all preservation within L2 and L4 groups (Table 2). The cooling period exhibited higher $(\mathrm{P} \leq 0.01)$ percentage of live sperm as compared with $3^{\text {rd }}$ and $6^{\text {th }}$ months PC periods in L3 and L9 groups (Table 2). Furthermore, non-significant differences were observed among all PC periods for similar trait and groups (Table 2). Higher $(\mathrm{P} \leq 0.0001)$ percentage was recorded at the cooling period as compared with $96 \mathrm{hrs}$., $3^{\text {rd }}$, and $6^{\text {th }}$ months PC periods in L12 group (Table 2). The 96 hrs. exhibited greater live sperm $(\%)$ in comparison with the $3^{\text {rd }}$ and $6^{\text {th }}$ months PC periods in L12 group (Table 2). The results revealed nonsignificant differences between L1 and L2 groups at different preservation periods (Table $2)$. These results were consistent with previous studies $(2,7,30,51)$ in bull and buck. The current results were disagreed with (30) who found higher $(\mathrm{P}<0.05)$ live sperm percentage in vitamin $\mathrm{E}$ groups $(0.134$ and 0.268 $\mathrm{mg} / 100 \mathrm{ml}$ ) as compared with the control group (Tris extender). Results demonstrated nonsignificant differences among vitamin $E$ groups (L8 and L11) as compared with swimup (L7) and glass wool (L10) groups at different preservation periods (Table 2). This may return to the insufficient amount of vitamin $E$ as antioxidants to scavenge the reactive oxygen species (ROS) and significant improvement of all semen characteristics. This confirmed the current results that all vitamin $\mathrm{E}$ groups (L2, L5, L8, and L11) were numerically higher than similar Tris groups (L1, L4, L7, and L10). The moderate level of ROS as hydrogen peroxide had no effect on the live sperms but inhibit the sperms motility through reducing the amount of ATP and phosphorylation of protein in exoneme (63). Many studies recommended using the synergistic or combined antioxidants (Synthetics or natural antioxidants) for reducing ROS and to improve semen quality at cooling and PC periods $(2,3,7,22,24,40$, 43). The differences in the live sperm percentages lacked significance between the SOD (L3) and the positive (L1) groups at different preservation periods (Table 2). These results were consistent with previous study (46), who didn't find significant differences in live sperm percentage between SOD (150 IU) and control group (Tris extender) at cooling of Mithun (Bos frontalis) bull semen. This may return to insufficient amount of SOD as mentioned above. The above results clarified that non-significant differences (Numerical improvement) in live sperm percentage among swim-up groups (L7-L9) as compared with a negative control group (L4) at different preservation periods (Table 2). The current results illustrated a higher $(\mathrm{P} \leq 0.0001)$ live sperm percentage in glass wool separation technique groups (L10-L12) as compared with low semen quality groups (L4-L6) at different preservation periods (Table 2). These results coincided with (58) findings who showed a higher $(\mathrm{P} \leq 0.01)$ live sperm percentage in glass wool filtration $(83.68 \pm 1.31 \%)$ than the unfiltered group $(70.78 \pm 1.96 \%)$ for fresh crossbred bull semen. The present results revealed no significant in live sperm percentage for glass wool separation technique groups (L10-L12) in comparison with good semen quality groups (L1-L3) at different preservation periods (Table 2). 
Table 2. Effect of swim-up and glass wool separation techniques and adding of superoxide dismutase or vitamin $\mathrm{E}$ to semen extender on post-cryopreserved (PC) live sperm (\%) of Holstein bulls semen (Mean \pm SE).

\begin{tabular}{|c|c|c|c|c|c|}
\hline Groups & $\begin{array}{c}\text { Cooling } \\
5^{\circ} \mathrm{C}\end{array}$ & $\begin{array}{l}96 \text { hrs } \\
\text { PC }\end{array}$ & $\begin{array}{l}3 \text { months } \\
\text { PC }\end{array}$ & $\begin{array}{l}6 \text { months } \\
\text { PC }\end{array}$ & $\begin{array}{c}\text { Level of } \\
\text { Significance }\end{array}$ \\
\hline L1 & $\begin{array}{c}88.43 \pm 1.17 \text { a } \\
A\end{array}$ & $\begin{array}{c}79.64 \pm 0.90 \mathrm{abc} \\
\text { B }\end{array}$ & $\begin{array}{c}77.07 \pm 1.56 \text { ab } \\
\text { B }\end{array}$ & $\begin{array}{c}76.29 \pm 1.72 \mathrm{ab} \\
\text { B }\end{array}$ & $P \leq 0.0001$ \\
\hline $\mathbf{L 2}$ & $\begin{array}{c}90.50 \pm 3.50 \mathrm{a} \\
\mathrm{A}\end{array}$ & $\begin{array}{c}85.00 \pm 2.00 \mathrm{a} \\
\mathrm{A}\end{array}$ & $\begin{array}{c}82.25 \pm 0.75 \text { a } \\
\text { A }\end{array}$ & $\begin{array}{c}81.25 \pm 3.25 \\
\mathrm{~A}\end{array}$ & N.S. \\
\hline L3 & $\begin{array}{c}89.63 \pm 2.11 \text { a } \\
A\end{array}$ & $\begin{array}{c}83.50 \pm 1.90 \text { ab } \\
\text { AB }\end{array}$ & $\begin{array}{c}78.38 \pm 2.63 \mathrm{ab} \\
\mathrm{B}\end{array}$ & $\begin{array}{c}76.88 \pm 1.52 \mathrm{ab} \\
\text { B }\end{array}$ & $P \leq 0.004$ \\
\hline L4 & $\begin{array}{c}77.29 \pm 2.32 \mathrm{c} \\
\mathrm{A}\end{array}$ & $\begin{array}{c}62.21 \pm 1.62 \mathrm{~d} \\
\mathrm{~A}\end{array}$ & $\begin{array}{c}58.36 \pm 1.59 \mathrm{f} \\
\mathrm{A}\end{array}$ & $\begin{array}{c}56.50 \pm 2.33 \mathrm{e} \\
\mathrm{A}\end{array}$ & N.S. \\
\hline L5 & $\begin{array}{c}77.50 \pm 2.55 \mathrm{c} \\
\mathrm{A}\end{array}$ & $\begin{array}{c}63.14 \pm 1.71 \mathrm{~d} \\
B\end{array}$ & $\begin{array}{c}60.71 \pm 2.11 \text { ef } \\
\text { B }\end{array}$ & $\begin{array}{c}59.36 \pm 2.03 \mathrm{e} \\
\text { B }\end{array}$ & $P \leq 0.0001$ \\
\hline L6 & $\begin{array}{c}78.00 \pm 2.06 \mathrm{c} \\
\mathrm{A}\end{array}$ & $\begin{array}{c}62.71 \pm 2.02 \mathrm{~d} \\
B\end{array}$ & $\begin{array}{c}60.36 \pm 1.60 \text { ef } \\
\text { B }\end{array}$ & $\begin{array}{c}58.71 \pm 1.03 \mathrm{e} \\
\text { B }\end{array}$ & $P \leq 0.0001$ \\
\hline L7 & $\begin{array}{c}77.07 \pm 1.93 \mathrm{c} \\
\mathrm{A}\end{array}$ & $\begin{array}{c}62.07 \pm 2.76 \mathrm{~d} \\
\mathrm{~B}\end{array}$ & $\begin{array}{c}68.71 \pm 2.74 \text { cde } \\
\text { B }\end{array}$ & $\begin{array}{c}58.00 \pm 2.93 \mathrm{e} \\
\text { B }\end{array}$ & $P \leq 0.0001$ \\
\hline L8 & $\begin{array}{c}79.64 \pm 2.81 \text { bc } \\
\mathrm{A}\end{array}$ & $\begin{array}{c}72.00 \pm 2.81 \mathrm{c} \\
\mathrm{B}\end{array}$ & $\begin{array}{c}68.00 \pm 3.85 \text { cde } \\
\text { B }\end{array}$ & $\begin{array}{c}64.93 \pm 3.67 \mathrm{cde} \\
\text { B }\end{array}$ & $P \leq \mathbf{0 . 0 0 3}$ \\
\hline L9 & $\begin{array}{c}79.29 \pm 3.18 \mathrm{c} \\
\mathrm{A}\end{array}$ & $\begin{array}{c}72.79 \pm 3.87 \mathrm{c} \\
\mathrm{AB}\end{array}$ & $\begin{array}{c}65.71 \pm 3.59 \text { def } \\
\text { B }\end{array}$ & $\begin{array}{c}63.43 \pm 2.57 \mathrm{de} \\
\text { B }\end{array}$ & $P \leq 0.01$ \\
\hline L10 & $\begin{array}{c}86.93 \pm 1.90 \\
A\end{array}$ & $\begin{array}{c}79.36 \pm 1.48 \mathrm{abc} \\
\text { B }\end{array}$ & $\begin{array}{c}75.79 \pm 1.56 \mathrm{abc} \\
\text { BC }\end{array}$ & $\begin{array}{c}71.64 \pm 1.45 \mathrm{bcd} \\
\mathrm{C}\end{array}$ & $P \leq 0.0001$ \\
\hline L11 & $\begin{array}{c}87.14 \pm 2.57 \mathrm{ab} \\
\mathrm{A}\end{array}$ & $\begin{array}{c}76.79 \pm 2.61 \mathrm{bc} \\
\text { B }\end{array}$ & $\begin{array}{c}73.50 \pm 2.87 \text { bcd } \\
\text { B }\end{array}$ & $\begin{array}{c}73.21 \pm 3.16 b c \\
\text { B }\end{array}$ & $P \leq 0.005$ \\
\hline L12 & $\begin{array}{c}87.29 \pm 1.53 \mathrm{ab} \\
\mathrm{A}\end{array}$ & $\begin{array}{c}81.21 \pm 1.75 \mathrm{ab} \\
\text { B }\end{array}$ & $\begin{array}{c}72.57 \pm 2.13 \text { bed } \\
\text { C }\end{array}$ & $\begin{array}{c}70.29 \pm 1.84 \mathrm{bcd} \\
\mathrm{C}\end{array}$ & $P \leq 0.0001$ \\
\hline $\begin{array}{c}\text { Level of } \\
\text { Significance }\end{array}$ & $P \leq 0.0001$ & $P \leq 0.0001$ & $P \leq 0.0001$ & $\mathbf{P} \leq \mathbf{0 . 0 0 0 1}$ & --- \\
\hline
\end{tabular}

Means with small superscripts within each column indicated significant differences among groups and large superscripts within each row indicated significant differences among periods; N.S.= no significant; L1= Good Semen Quality $($ GSQ) + Tris extender; L2= GSQ + Tris extender + 2 mM vitamin E; L3= GSQ + Tris extender + 200 IU SOD; L4= Low Semen Quality (LSQ) + Tris extender; L5 = LSQ + Tris extender + 2 mM vit. E; L6= LSQ + Tris extender + 200 IU SOD; L7= SU Semen tech.+Tris extender; L8= SU Semen tech.+ Tris extender $+2 \mathrm{mM}$ vit. E; L9= SU Semen tech.+Tris extender + 200 IU SOD; L10= GW Semen tech.+ Tris extender; L11= GW Semen tech.+ Tris extender + 2mMvit. E, L12= GW Semen tech.+Tris extender + 200 IU SOD.

\section{Total abnormalities percentages}

The results of total abnormalities percentages for Holstein bull's semen revealed significant differences $(\mathrm{P} \leq 0.0001)$ among all groups at cooling (Table 3). The L2 group recorded lowest percentages of total abnormalities $(1.50 \pm 0.50 \%)$ at cooling (Table 3). The L4 $(13.21 \pm 2.06 \%)$ and L6 $(13.93 \pm 1.21 \%)$ groups exhibited higher total abnormalities at cooling (Table 3). Non- significant differences $(\mathrm{P} \leq 0.0001) \quad$ were observed in total abnormalities percentages among L1, L2, and L7-L11 as well among L1 and L7-L12 also among L3, L5, and L12 at cooling (Table 3). The L2 (4.75 $\pm 0.75 \%)$, L11 $(4.30 \pm 0.34 \%)$, L8 $(4.93 \pm 0.41 \%)$ and L10 $(6.06 \pm 0.66 \%)$ groups had lesser $(\mathrm{P} \leq 0.0001)$ total abnormalities at 96 hrs. PC period (Table 3). The L4 group $(21.79 \pm 2.46 \%)$ showed greater total abnormalities at $96 \mathrm{hrs}$. PC period (Table 3). Non- significant differences $\quad(\mathrm{P} \leq 0.0001)$ among L1-L2 and L7-L12 groups at 96 hrs.
PC period (Table 3). The L1-L2 and L7-L12 groups demonstrated lower $(\mathrm{P} \leq 0.0001)$ total abnormalities percentages as compared with L4-L6 groups at $3^{\text {rd }}$ months PC period (Table $3)$. Non-significant differences $(\mathrm{P} \leq 0.0001)$ were noticed among L1-L2 and L7-L12 groups as well among L4-L6 groups at $3^{\text {rd }}$ months PC period (Table 3). The total abnormalities percentage was significantly $(\mathrm{P} \leq 0.0001)$ decreased in L1, L2, and L7-L112 groups as compared with L4-L6 at $6^{\text {th }}$ month PC period (Table 3). The differences among L1-L2, L7L8, and L10-L12 groups lacked significance at $6^{\text {th }}$ month PC period (Table 3). Nonsignificant differences were observed among L3, L7 and L9 and L12 groups as well among L3, L5, and L9 groups at $6^{\text {th }}$ month PC period (Table 3). No significant differences were illustrated between L2 ( $2 \mathrm{mM}$ vitamin E) and L1 (Good quality, Tris extender) groups at all preservation periods. These results were in line with (25) who didn't find significant 
differences in total abnormalities percentage between control group (Tris extender) and vitamin $\mathrm{E}$ group $(0.2 \mathrm{mM}$ vitamin $\mathrm{E})$ at different preservation periods. Also, the current results were concurrent with (30) who didn't found significant differences in total abnormalities percentages between control group (Tris extender) and vitamin $\mathrm{E}$ group (0.402 $\mathrm{gm} / 100 \mathrm{ml}$ vitamin E) at PC period in Simmental bull semen The adding of vitamin E to semen extender would provide protection to cell membrane from free radicals, so that it would reduce the possibility of damages leading to sperm cell abnormality and mortality (30). The L3 group (200 IU SOD, good semen quality) exhibited higher percentage of total abnormalities as compared with the L1 group (Tris extender, good semen quality). However, they both remain within the normal acceptable sperm abnormalities percentages $(<20 \%)$. The SOD is an important antioxidant enzyme which rapidly catalyzes the dismutation of superoxide anion $\left(\mathrm{O}^{-\cdot}\right)$ and thus, acts as a first line antioxidant defense (20). The priority of antioxidants is to protect the genetic material in the nucleus (DNA) from free radical damage (9). The adding of SOD to low quality semen groups (with or without sperm separation techniques) was decreased total abnormalities as compared with L4 group. SOD, in sperm cells is able to react with many reactive oxygen species directly for protecting mammalian cells against oxidative stress (15), and hence maintaining viability, normal morphology and sperm motility. Further, SOD, a permeating cryoprotectant, acts as an antioxidant and causes membrane lipid and protein rearrangement, which results in increased membrane fluidity, more dehydration at lower temperatures preservation $\left(-196^{\circ} \mathrm{C}\right)$, and therefore increased ability of sperm to survive during this preservation (33). The results demonstrated a reduction in total abnormalities at all preservation periods by using swim-up sperm separation techniques (Table 3). The current results were agreed with (1) finding who found a reduction in total abnormalities percentage between swim-up filtration and control group $(8.80 \pm 0.57$ vs. $18.80 \pm 1.94 \%)$ of buffalo bull semen. The present results of total abnormalities percentage by glass wool separation technique were consistent with Vyas (58) finding. The present results of total abnormalities percentage by swim-up and glass wool separation techniques were reduction as compared with L4 group (negative control) and no significant differences with L1 group. A reduction in the percentages of total abnormalities is regarded as normal response for sperm activity and morphology after removal of seminal plasma, since it contains dead and abnormal sperms, leukocytes, epithelial cells, debris and microbial contamination that produce many oxygen radicals that negatively influence the sperm functions (16). 
Table 3. Effect of swim-up and glass wool separation techniques and adding of superoxide dismutase or vitamin $\mathbf{E}$ to semen extender on post-cryopreserved (PC) total abnormalities percentages of Holstein bulls (Mean \pm SE).

\begin{tabular}{|c|c|c|c|c|c|}
\hline Groups & $\begin{array}{c}\text { Cooling } \\
5^{\circ} \mathrm{C}\end{array}$ & $\begin{array}{l}96 \text { hrs. } \\
\text { PC }\end{array}$ & $\begin{array}{c}3 \text { months } \\
\text { PC }\end{array}$ & $\begin{array}{c}6 \text { months } \\
\text { PC }\end{array}$ & $\begin{array}{c}\text { Level of } \\
\text { Significance }\end{array}$ \\
\hline L1 & $\begin{array}{c}3.21 \pm 0.55 \mathrm{cde} \\
\text { B }\end{array}$ & $\begin{array}{c}7.22 \pm 0.89 \mathrm{~cd} \\
\mathrm{~A}\end{array}$ & $\begin{array}{c}7.57 \pm 1.28 \mathrm{de} \\
\mathrm{A}\end{array}$ & $\begin{array}{c}8.71 \pm 1.29 \mathrm{e} \\
\mathrm{A}\end{array}$ & $\mathrm{P} \leq \mathbf{0 . 0 0 7}$ \\
\hline $\mathbf{L 2}$ & $\begin{array}{c}1.50 \pm 0.50 \mathrm{e} \\
\mathrm{A}\end{array}$ & $\begin{array}{c}4.75 \pm 0.75 d \\
A\end{array}$ & $\begin{array}{c}7.67 \pm 2.96 \text { de } \\
\text { A }\end{array}$ & $\begin{array}{c}8.67 \pm 2.60 \mathrm{e} \\
\mathrm{A}\end{array}$ & N.S. \\
\hline $\mathbf{L 3}$ & $\begin{array}{c}6.63 \pm 1.14 \\
\text { B }\end{array}$ & $\begin{array}{c}10.25 \pm 1.38 \mathrm{c} \\
\mathrm{AB}\end{array}$ & $\begin{array}{c}13.50 \pm 1.19 b c \\
A\end{array}$ & $\begin{array}{c}15.50 \pm 3.52 \mathrm{~cd} \\
\mathrm{~A}\end{array}$ & $P \leq 0.04$ \\
\hline L4 & $\begin{array}{c}13.21 \pm 2.06 \mathrm{a} \\
\mathrm{B}\end{array}$ & $\begin{array}{c}21.79 \pm 2.46 \text { a } \\
\mathrm{A}\end{array}$ & $\begin{array}{c}22.14 \pm 2.90 \mathrm{a} \\
\mathrm{A}\end{array}$ & $\begin{array}{c}24.57 \pm 2.39 \text { a } \\
A\end{array}$ & $P \leq 0.02$ \\
\hline L5 & $\begin{array}{c}8.64 \pm 1.60 \text { b } \\
\text { B }\end{array}$ & $\begin{array}{c}15.65 \pm 1.31 \mathrm{~b} \\
\mathrm{~A}\end{array}$ & $\begin{array}{c}17.43 \pm 0.88 \mathrm{ab} \\
\mathrm{A}\end{array}$ & $\begin{array}{c}17.22 \pm 1.69 \\
\mathrm{~A}\end{array}$ & $P \leq 0.0003$ \\
\hline L6 & $\begin{array}{c}13.93 \pm 1.21 \text { a } \\
\text { B }\end{array}$ & $\begin{array}{c}16.22 \pm 0.99 \mathrm{~b} \\
\mathrm{~B}\end{array}$ & $\begin{array}{c}19.59 \pm 1.02 \mathrm{ab} \\
\mathrm{A}\end{array}$ & $\begin{array}{c}21.01 \pm 1.09 a b \\
A\end{array}$ & $P \leq 0.0005$ \\
\hline L7 & $\begin{array}{c}4.43 \pm 0.61 \mathrm{cde} \\
\text { C }\end{array}$ & $\begin{array}{c}7.21 \pm 0.83 \mathrm{~cd} \\
\text { B }\end{array}$ & $\begin{array}{c}8.43 \pm 0.72 \mathrm{de} \\
\mathrm{AB}\end{array}$ & $\begin{array}{c}9.57 \pm 0.78 \mathrm{de} \\
\mathrm{A}\end{array}$ & $P \leq 0.0004$ \\
\hline L8 & $\begin{array}{c}2.57 \pm 0.40 \mathrm{de} \\
\text { D }\end{array}$ & $\begin{array}{c}4.93 \pm 0.41 \mathrm{~d} \\
\mathrm{C}\end{array}$ & $\begin{array}{c}6.28 \pm 0.53 \mathrm{e} \\
\mathrm{B}\end{array}$ & $\begin{array}{c}7.78 \pm 0.31 \mathrm{e} \\
\mathrm{A}\end{array}$ & $P<0.0001$ \\
\hline L9 & $\begin{array}{c}4.57 \pm 0.47 \mathrm{cde} \\
\text { B }\end{array}$ & $\begin{array}{c}8.14 \pm 0.78 \mathrm{~cd} \\
\text { B }\end{array}$ & $\begin{array}{c}11.79 \pm 1.51 \mathrm{~cd} \\
\mathrm{~A}\end{array}$ & $\begin{array}{c}13.65 \pm 1.70 \mathrm{~cd} \\
\mathrm{~A}\end{array}$ & $\mathrm{P}<0.0001$ \\
\hline L10 & $\begin{array}{c}2.50 \pm 0.18 \mathrm{de} \\
\mathrm{C}\end{array}$ & $\begin{array}{c}6.06 \pm 0.66 \mathrm{~d} \\
\text { B }\end{array}$ & $\begin{array}{c}7.54 \pm 0.53 \mathrm{e} \\
\mathrm{AB}\end{array}$ & $\begin{array}{c}8.57 \pm 0.84 \mathrm{e} \\
\mathrm{A}\end{array}$ & $P \leq 0.0001$ \\
\hline L11 & $\begin{array}{c}2.22 \pm 0.19 \mathrm{de} \\
\mathrm{C}\end{array}$ & $\begin{array}{c}4.30 \pm 0.34 \mathrm{~d} \\
\mathrm{~B}\end{array}$ & $\begin{array}{c}5.31 \pm 0.43 \mathrm{de} \\
\text { AB }\end{array}$ & $\begin{array}{c}6.27 \pm 0.68 \mathrm{e} \\
\mathrm{A}\end{array}$ & $P \leq 0.0001$ \\
\hline L12 & $\begin{array}{c}5.32 \pm 0.35 \text { bcd } \\
\text { C }\end{array}$ & $\begin{array}{c}7.28 \pm 0.43 \mathrm{~cd} \\
\text { B }\end{array}$ & $\begin{array}{c}9.45 \pm 0.66 \mathrm{de} \\
\mathrm{A}\end{array}$ & $\begin{array}{c}10.58 \pm 0.90 \mathrm{de} \\
\mathrm{A}\end{array}$ & $P \leq 0.0001$ \\
\hline $\begin{array}{c}\text { Level of } \\
\text { Significance }\end{array}$ & $P \leq 0.0001$ & $P \leq 0.0001$ & $\mathbf{P} \leq \mathbf{0 . 0 0 0 1}$ & $\mathbf{P} \leq \mathbf{0 . 0 0 0 1}$ & --- \\
\hline
\end{tabular}

Means with small superscripts within each column indicated significant differences among groups and large superscripts within each row indicated significant differences among periods; N.S.= no significant; L1= Good Semen Quality (GSQ) + Tris extender; $\mathrm{L} 2=\mathrm{GSQ}+$ Tris extender $+2 \mathrm{mM}$ vitamin $\mathrm{E}$; L3= GSQ + Tris extender + 200 IU SOD; L4= Low Semen Quality (LSQ) + Tris extender; $\mathrm{L} 5=\mathrm{LSQ}+$ Tris extender $+2 \mathrm{mM}$ vit. $\mathrm{E}$; $\mathrm{L6}=$ $\mathrm{LSQ}+$ Tris extender + $200 \mathrm{IU}$ SOD; $\mathrm{L} 7=\mathrm{SU}$ Semen tech.+Tris extender; L8 $=$ SU Semen tech.+ Tris extender $+2 \mathrm{mM}$ vit. $\mathrm{E} ; \mathrm{L} 9=\mathrm{SU}$ Semen tech.+Tris extender + 200 IU SOD; L10 $=$ GW Semen tech.+ Tris extender; L11= GW Semen tech.+ Tris extender +2 mMvit. E, L12 = GW Semen tech. + Tris extender +200 IU SOD.

\section{REFERENCES}

1. Abdel-Razek, K.H., A. H. Hussien, W. Senosy, and M. S. Yousef. 2017. Effect of sperm separation methods on morphology and functions of frozen buffalo spermatozoa. J. Adv. Vet. Res., 7:18-23.

2. Abdulkareem, T. A. and O. H. Al-Zaidi. 2018. Effect of adding aqueous extract of Melissa officinalis leaves and some other antioxidants to milk-based extender on postcooling and post cryopreservative sperm' $\mathrm{s}$ individual motility and live sperm percentage of Holstein bulls. Al-Anbar J. Vet. Sci., 11 (1), 37-53

3. Abdulkareem, T.A., M. S. Noon, and K. H. Sultan. 2017. The synergistic Influence of some antioxidants added to Tris extender on sperm cells individual motility of Holstein bulls following different cooling and cryopreservation periods. Al-Anbar J. Vet. Sci., 10(1), 10-20

4. Abdulkareem, T.A., O. A. Mohamed, A. M. H. Shubber, F. F. Ibrahim, and W. Y. Lataf. 2016. Effect of adding carnitine and inositol to Tris extender on post cryopreservative semen quality of Holstein bulls. Al-Anbar J. Vet. Sci., 9(1), 8-18

5. Al Dulaimy, M.T.S., S. M. Eidan, and S. H. Al Azzawi. 2019. Genetic polymorphism to heat shock protein (HSP90AA1) gene and association with characteristics of heat tolerance in bulls. Biochem. Cell. Arch., 19(1), 1605-1611

6. Al-Murshdi, M. K. and Y. K. Al-Sultani. 2016. Effect Invitro Activation on the 
Spermiograms of Oligozoospermic Patients. Kufa J. Nurs. Sci., 6(1), 78-83.

7. Al-Zaidi, O.H. 2014. Adding some Antioxidants and Omega 3 to Tris Extender and Effect on Activating Post-cryopreservative Semen Quality Characteristics of Holstein Bulls. M.Sc. Thesis, College of Agriculture, University of Baghdad.

8. Amann, R. and R. H. Hamnerstedt. 2002. Detection of differences in fertility. J. Androl., 23, 317-325

9. Ammar, R.B., T. Miyamoto, L. ChekirGhedira, and K. Ghedira. 2019. Isolation and identification of new anthraquinones from Rhamnus alaternus $\mathrm{L}$ and evaluation of their free radical scavenging activity. Nat. Prod. Res., 33 (2), 280-286

10. Arias, M.E., K. Andara, E. Briones, and R. Felmer. 2017. Bovine sperm separation by Swim-up and density gradients (Percoll and BoviPure): Effect on sperm quality, function and gene expression. Biol. Reprod., 17, 126132

11. Arzondo, M.M., J. N. Caballero, C. I. Marín-Briggiler,. G. Dalvit, P. D. Cetica, . and M. H. Vazquez-Levin. 2012. Glass wool filtration of bull cryopreserved semen: a rapid and effective method to obtain a high percentage of functional sperm. Theriogenology, 78(1), 201-209

12. Asadpour, R., R. Jafari, and H. TayefiNasrabadi, 2012. The effect of antioxidant supplementation in semen extenders on semen quality and lipid peroxidation of chilled bull spermatozoa. Iranian J. Vet. Res., 13 (3), 246249

13. Beheshti, R., A. Asadi, and N. Maheri-Sis. 2011. The effect of vitamin $\mathrm{E}$ on post-thawed buffalo bull sperm parameters. J. Am. Sci. 7(6), 227-231.

14. Beydola, T., R.K., Sharma and W. Lee. 2013. Sperm preparation and selection techniques. In: Rizk B, Aziz N and Agarwal A. Editors. Male Infertility Practice. New Delhi: Jaypee Brothers Medical Publishers. , 244-251.

15. Bilodeau, J.F., S. Blanchette, C. Gagnon, and M.A. Sirard. 2001. Thiols prevent H2O2mediated loss of sperm motility in cryopreserved bull semen. Theriogenology, 56:275-286.
16. Bjorndahl, L., M. Mohammadieh, M. Pourian, I. Soderlund and U. Kvist, 2005. Contamination by seminal plasma factors during sperm selection. J of Androl, (2),170-

17. Burton, G.W., and K.U. Ingold. 1986. Vitamin E: application of the principles of physical organic chemistry to the exploration of its structure and function. Acc. Chem. Res., 19(7),194-201.

18. Daghigh, K.H. and R. Karaji. 2017. Effect of reduced glutathione and superoxide dismutase antioxidants levels on some of characteristic of sperm after freezing bull semen. J of Veterinary Research. (72),377-384 19. de Lamirande, E. and C. Gagnon. 1995. Impact of reactive oxygen species on spermatozoa: a balancing act between beneficial and detri-mental effects. Human Reproduction, 10(1),15-21

20. Di Naso, F.C., A. Simões Dias, M. Porawski and N.A. Marroni. 2011. Exogenous superoxide dismutase: Action on liver oxidative stress in ani- mals with streptozotocin-induced diabetes. Exp. Diabetes Res., 1-6

21. Duncan, D.B. 1955. Multiple Rang and Multiple F-test. Biometrics.11:1-24

22. Eidan, S.M. 2016. Effect on postcryopreserved semen characteristics of Holstein bulls of adding combinations of vitamin $\mathrm{C}$ and either catalase or reduced glutathione to Tris extender. Anim. Reprod. Sci., 167: 1-7

23. Eidan, S.M. and O.H.A. Al-Zaidi. 2017. Effect of adding some vitamins, omega 3 and their combinations to Tris extender on some acrosome deformation percentage of Holstein bulls after different preservation periods. Iraqi. J. Agric. Res., 22(4),117-128

24. Eidan, S.M., T.A. Abdulkareem, and O.A.A. Sultan. 2015. Influence of adding manganese to Tris extender on some postcryopreservation semen attributes of Holstein bulls. IJAAS., 1: 26-30

25. Eidan, S.M., F.F. Ibrahim, T.A. Abdulkareem and K.F. Hurish. 2017. Effect of post foot and mouth disease infection on some semen attributes and blood biochemical parameters of Holstein bulls. I.J.S.N., 8(3):557-560

26. Erben-Russ, M., Michel, C., Bors, W. and Saran, M. 1987. Absolute rate constant of 
alkoxyl radical reactions in aqueous solution. The Journal of Physical Chemistry, 91(9).

27. Garcia-Herreros, and Leal, C.L.V. 2014. Comparative study of sperm washing and selection methods after cryopreservation and its influence on sperm subpopulational structure in a bovine model. Syst Biol Reprod Med., 60(6), 338-347

28. Griveau, J., P. Renard, and D. Le Lannou. 1995. Superoxide anion production by human spermatozoa as a part of the ionophoreinduced acrosome reaction process. Int. J. Androl., 18(2),67-74

29. Hancock, J. L. 1951. A staining technique for the study of temperature shock in semen. Nature, 167: 323-324

30. Haris, F.Z., Ondho,Y.S., and Samsudewa, D. 2020. Effect of vitamin E addition to frozen Simmental bull semen extender on postthawing quality. E3S Web Conf. Volume 142. The 3rd International Conference on Agricultural and Life Sciences

31. Heidar, M., N. Lakpour, and M.R. Sadeghi. 2018. Upstream or swim up processing technique: which one is more effective to select human sperm with high chromatin integrity. Int. J. Reprod. Biomed. (Yazd). 16(7),463-468

32. Henkel, R.R. and W.B. Schill, 2003. Sperm preparation for ART. Reprod Biol. Endocrinol.; 1: 108.

33. Holt, W.V. 2000. Basic aspects of frozen storage of semen. Anim. Reprod Sci. 62: 3-22 34. $\mathrm{Hu}, \mathrm{L}, \mathrm{T}$. Huang, X.J. Liu and Y.D. Cai. 2011. Predicting protein phenotypes based on protein-protein interaction network. PLoS One 6(3), 17668

35. Jameel, T. 2008. Sperm swim-up: a simple and effective technique of semen processing for intrauterine insemination. $\mathrm{J}$ Pak Med Assoc., 58(2), 71-74

36. Lee, H., S. Kim, D. Ji and Y. Kim. 2009. A comparative study of sephadex, glass wool and percoll separation techniques on sperm quality and IVF results for cryopreserved bovine semen. J. Vet. Sci., 10 (3), 249-255

37. Losano, J.D.A., D.S.R. Angrimani, B.R. Rui, L.C. Bicudo, A. Dalmazzo, B.C.S. Silva, C.C. Viana, C.M. Mendes, M.E.O.A. Assumpção, Barnabe, V.H. and M. Nichi. 2018. The addition of docosahexaenoic acid (DHA) and antioxidants (glutathione peroxidase and superoxide dismutase) in extenders to epididymal sperm cryopreservation in bulls. Zygote, 26(3),199206.

38. Mehmood, A., M. Anwar and S.M. Saqlan. 2009. Motility, acrosome integrity, membrane integrity and oocyte cleavage rate of sperm separated by swim-up or Percoll gradient method from frozen-thawed buffalo semen. Anim. Reprod. Sci., 111: 141-148.

39. Mohammed O.A., T.A. Abdulkareem, F.F. Ibrahim, O.H. Al-Zaidi, W.E. Latif, and S.H. Alwan. 2020. Effect of adding pentoxifylline and nitric oxide to Tris extender on some postcryopreserved semen attributes of Holstein bulls. Iraqi J. Agric. Sci., 51(2),619-628

40. Mohsin, A.S. and S.M. Eidan. 2019. Effect of adding antioxidants to Tris extender on cooling and post- Cryopreservative semen characteristics of Holstein bulls 2. Salvia Officinalis L Aqueous extract. Biochem. Cell. Arch., 19(1),1157-1164

41. Murtaza, A., M. Ahmad, M. Zubair and S. Umar. 2017. Comparative effects of addition of superoxide dismutase and reduced glutathione on cryopreservation of Sahiwal bull semen. Reprod. Domest. Anim., 52(Suppl. 3), 66-146

42. Murtaza, A., M. Ahmad, M. Zubair, S. Umar, A. Mushtaq, A.H.S.T. Gul, and A.U. Khan. 2018. Comparative effects of addition of superoxide dismutase and reduced glutathione on cryopreservation of Sahiwal bull semen. J, Hellenic Vet. Med. Soc., 2018, 69(4), 1291-1296

43. Noon, M.S., T.A. Abdulkareem, and K.H. Sultan. 2017. The synergistic effect of adding some antioxidants to Tris extender on total sperm abnormalities percentage of Holstein bulls cooling cooling and cryopreservation. Al-Anbar Journal of Veterinary Sciences, 15, 455-466

44. Parrish, J.J., J.L. Susko-Parrish, M.L. Leibfried-Rutledge, E.S. Crister, W.H. Eyestone, and N.L. First. 1986. Bovine in vitro fertilization with frozen thawed semen. Theriogenology, 25, 591-600'

45. Pekmezci, D. 2011. Vitamin E and immunity. Vitam Horm.; 86,179-215.

46. Perumal, P. 2014. Effect of superoxide dismutase on semen parameters and antioxidant enzyme activities of liquid stored 
$\left(5^{\circ} \mathrm{C}\right)$ Mithun (Bos frontalis) semen. J. Anim. $14,1-9$

47. Perumal, P., K. Vupru and C. Rajkhowa. 2013. Effect of addition of taurine on the liquid storage $\left(5^{\circ} \mathrm{C}\right)$ of mithun (Bos frontalis) semen. Veterinary Medicine International, vol., Article ID 165348, 7 pages

48. Rao, T.K.S., N. Kumar, N.B. Patel, I. Chauhan and S. Chaurasia. 2013. Sperm selection techniques and antioxidant fortification in low grade semen of bulls: Review, Vet. World., 6(8), 579-585

49. Risopatrón, J., R.N. Sánchez-Sepúlveda, P. Peña, E. Villagran and W. Miska. 1996. Migration/sedimentation sperm selection method used in bovine in vitro fertilization: Comparison with washing/centrifugation. Theriogenology, 46,65-73

50. Salisbury, G.W., N.L. Van Demark, and J.R. Lodge. 1978. Physiology of Reproduction and Artificial Insemination of cattle. 2nd edi. W.H. Freeman \& Co., San Francisco. p. 326353

51. Sarangi, A., P. Singh, M. Virmani, A.S. Yadav, S. Sahu, M. Ajithakumar, A. Kumari and A.P Rath. 2017. Effect of antioxidants supplementation on the quality of Beetal buck semen stored at $4^{\circ} \mathrm{C}$. Veterinary World, 10(10), 1184-1188

52. SAS. 2012. SAS/STAT User's Guide for Personal Computers. Release 9.1 SAS Institute Inc., Cary, N. C., USA

53. Sikka, S. C. 2004. Role of oxidative stress and antioxidants in andrology and assisted reproductive technology. J. Androl., 25, 5-18

54. Swanson, E. W. and H.J. Beardon. 1951. An eosin nigrosin stain differentiating live and dead bovine spermatozoa. J. Anim. Sci., 10:981-987
55. Traber, M.G. 1999. Utilization of vitamin E. Bio Factors, 10:3115-120

56. Valeanu, S., D. Drugociu, P. Rosca. 2015. Effect of Single layer centrifugation using Bovipure on frozen-thawed bovine sperm during a 6 hours survival test. Romanian Biotechnological Letters, 20(2), 10327-10333

57. Volpes, A., F. Sammartano, S. Rizzari, S. Gullo, A. Marino and A. Allegra. 2016. The pellet swim-up is the best technique for sperm preparation during in vitro fertilization procedures. J Assist Reprod Genet, 33, 765770

58. Vyas, S., G. Mohan, A.J. Dhami and K.L. Sahani. 1992. Effect of filtration through sephadex and glass wool on the quality and freezability of semen of crossbred bulls. Indian J. Anim. Sci., 62, 341-343

59. Walton, A. 1933. Technique of artificial insemination. mp. Bur. Anim. Genet. 56, IiiusEdinburgh

60. Yamauchi, R. 1997. Vitamin E: Mechanism of its antioxidant activity. Food Sci. Technol. Int. Tokyo, 3(4): 301-309

61. Yue, D., L. Yan, H. Luo, X. Xu and X. Jin. 2010. Effect of Vitamin E suplementation on semen quality and the testicular cell membranal and mitochondrial antioxidant abilities in Aohan fine-wool sheep. Anim. Reprod. Sci., 118(2-4),217-22

62. Zavos, P.M. 1992. Preparation of human frozen-thawed seminal specimens using the SpermPrep filtration method: improvements over the conventional swim up method. Fertil. Steril., 57, 1326-1330

63. Zubair, M. 2017. Effects of dietary vitamin E on male reproductive system. Asian Pacific Journal of Reproduction, 6(4),145-150. 